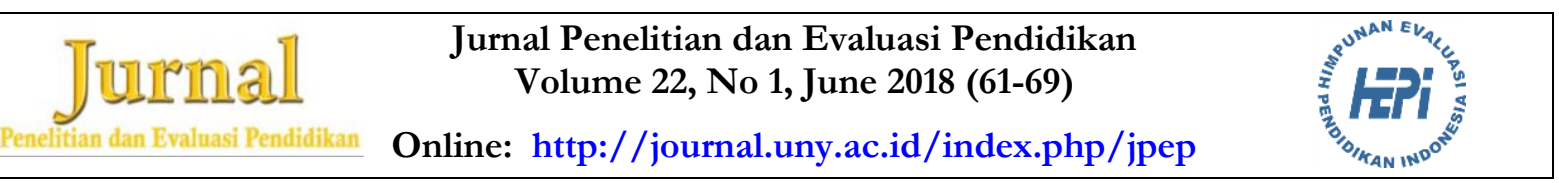

\title{
EVALUASI PELAKSANAAN STANDAR PROSES PENDIDIKAN PADA SMP NEGERI DI KABUPATEN SLEMAN
}

\author{
Lantip Diat Prasojo ${ }^{1}$, Fredrik Abia Kande ${ }^{2}$, Amirul Mukminin ${ }^{3}$ \\ ${ }^{1}$ Universitas Negeri Yogyakarta, ${ }^{2}$ Universitas Tribuana Kalabahi, ${ }^{3}$ Universitas Jambi \\ ${ }^{1}$ Jl. Colombo No. 1, Depok, Sleman 55281, Yogyakarta, Indonesia \\ ${ }^{2}$ Welai Tim., Tlk. Mutiara, Kabupaten Alor, Nusa Tenggara Timur, Indonesia \\ ${ }^{3}$ Mendalo Darat, Jambi Luar Kota, Kota Jambi, Jambi 36122, Indonesia \\ * Corresponding Author. Email: lantip@uny.ac.id
}

\begin{abstract}
Abstrak
Penelitian ini merupakan penelitian evaluasi yang bertujuan untuk mengungkapkan tingkat keefektivan pelaksanaan standar proses pendidikan. Model evaluasi yang digunakan adalah discrepancy evaluation model, Provus. Sampel penelitian ini adalah kepala sekolah dan guru di SMP Negeri Kabupaten Sleman. Pengumpulan data dilakukan dengan menggunakan angket, wawancara, dan dokumentasi. Berdasarkan analisis kuantitatif yang dilakukan, diketahui implementasi standar proses pada aspek perencanan pembelajaran, pelaksanaan, penilaian, dan pengawasan termasuk dalam kategori sangat efektif. Lebih lanjut diketahui bahwa implementasi standar di sekolah didukung oleh lingkungan kelas yang kondusif, peserta didik kooperatif, dan peran kepala sekolah. Inovasi media pembelajaran, proses memotivasi peserta didik, perolehan informasi baru tentang materi tambahan, dan pengidentifikasian kemampuan peserta didik merupakan faktor yang menghambat pelaksanaan standar proses.
\end{abstract}

Kata kunci: pelaksanaan standar proses, pendidikan

\section{AN EVALUATION OF THE IMPLEMENTATION OF EDUCATION PROCESS STANDARD ON JUNIOR HIGH SCHOOL IN SLEMAN REGENCY}

\begin{abstract}
This study is an evaluation research which is aimed at revealing the effectiveness level of the implementation of educational process standard. The evaluation model used in this research was discrepancy evaluation model, Provus. The samples of the research were the principals and teachers in state junior high schools in Sleman Regency. The data were collected using questionnaires, interviews, and documentation. Based on the quantitative analysis which had been conducted, the implementation of process standard on the aspects of planning, implementing, assessing, and supervising the learning process is considered to be very effective. Further, it is also revealed that the implementation of standard at school is supported by the conducive class environment, cooperative students, and the principal's role. Learning media innovation, the process in motivating the learners, the acquisition of new information on additional material, and the identification process of the learners' ability are considered as the inhibiting factors of the implementation of the process standard.
\end{abstract}

Keywords: implementation of process standard, education

Permalink/DOI: http:/ / dx.doi.org/10.21831/pep.v22i1.19018

Jurnal Penelitian dan Evaluasi Pendidikan

ISSN 1410-4725 (print) ISSN 2338-6061 (online) 


\section{Pendahuluan}

Pemerintah Indonesia saat ini terus mengupayakan peningkatan mutu pendidikan. Data dari The Learning Curve Pearson 2014 (Lestarini, 2014), menunjukkan bahwa mutu pendidikan Indonesia berada di posisi paling bawah atau rangking 40. Lembaga survei internasional lainnya, PISA (Programme for Internasional Student Assessment) mensurvei 61 negara dan menempatkan Indonesia di posisi 60. Walaupun sering memenangkan berbagai olimpiade internasional dalam bidang akademik maupun nonakademik, namun secara keseluruhan pendidikan di Indonesia masih jauh dari kata berkualitas.

Pemerintah Indonesia sesungguhnya telah menetapkan standar yang harus dicapai oleh sekolah untuk menjaminkan pelaksanaan di lapangan, yang meliputi Standar kompetensi lulusan (SKL), standar isi, standar proses, standar pendidik dan tenaga kependidikan, standar pengelolaan, standar sarana dan prasarana, standar pembiayaan, dan standar penilaian. Pada tingkat pelaksanaannya sekolah harus merencanakan dan melaksanakan standar-standar tersebut agar mutu pendidikan dapat ditingkatkan.

Salah satu bukti nyata direncanakan dan dilaksanakannya standar-standar tersebut dapat dilihat dari pelaksanaan proses pembelajaran. Kegiatan ini merupakan inti dari pelaksanaan pendidikan di sekolah. Oleh karena itu, kegiatan pembelajaran harus dikelola dengan baik oleh pelaku pendidikan terutama guru. Pengelolaan dalam kegiatan pembelajaran disebut dengan manajemen pembelajaran.

Menurut Usman (2014, p. 7), tujuan dan manfaat manajemen pembelajaran adalah (1) terciptanya suasana belajar dan proses pembelajaran yang aktif, inovatif, efektif, kreatif, dan menyenangkan, (2) terciptanya peserta didik yang aktif mengembangkan potensi dirinya untuk memiliki kekuatan spiritual keagamaan, pengendalian diri, kepribadian, kecerdasan, akhlak mulia, serta ketrampilan yang diperlukan dirinya untuk masyarakat, bangsa, dan negara dan (3) terpenuhinya salah satu dari 4 kompetensi guru.
Begitu pentingnya pengelolaan pembelajaran, maka tenaga pendidik perlu memiliki pemahaman yang baik mengenai konsep, prinsip, maupun prosedur pembelajaran. Di samping itu pengenalan tentang karakteristik dan tipologi peserta didik secara baik akan membantu tenaga pendidik mewujudkan suasana belajar mengajar yang PAIKEM (pembelajaran aktif, inovatif, kreatif, efektif, dan menyenangkan) serta sesuai dengan perkembangan dan karakteristik kebutuhan peserta didik.

Kebutuhan peserta didik sangat bervariasi dan menyangkut kondisi sosialbudaya. Hal ini terjadi karena setiap peserta didik memiliki latar belakang sosial budaya, ekonomi, kondisi geogrfis, dan kebiasaan yang berbeda-beda. Berbagai perbedaan ini menuntut ketanggapan tenaga pendidik dalam mengembangkan kurikulum dan pembelajaran yang mampu memenuhi sebagian atau keseluruhan kebutuhan tersebut.

Provinsi yang menjadi salah satu potret dari keberagaman peserta didik adalah Provinsi Daerah Istimewa Yogyakarta (DIY). Provinsi DIY merupakan kota tujuan utama peserta didik dari berbagai daerah di Indonesia, sehingga mendapatkan predikat sebagai kota pendidikan. Predikat ini semakin bermakna jika melihat prestasi satuan pendidikan dalam beberapa tahun terakhir yang mendominasi peringkat teratas.

Hal ini akan menjadi menarik, apabila prestasi beberapa satuan pendidikan di Provinsi DIY dikaji berdasarkan standar proses. Pencapaian standar proses akan membuktikan bahwa terdapat kesesuaian antara input, proses, dan output yang dihasilkan oleh satuan pendidikan di DIY.

Berdasarkan uraian di atas, penelitian evaluasi yang bertujuan untuk mengevaluasi pelaksanaan standar proses pendidikan perlu dilaksnakan, sehingga dapat diketahui apakah prestasi sekolah-sekolah tersebut dari segi output didukung oleh kualitas proses yang sesuai dengan standar pendidikan. Penelitian ini dilakukan di beberapa sekolah pada jenjang SMP di Kabupaten Sleman, mengingat beberapa sekolah di kabupaten ini menduduki peringkat lima besar di Pro- 
vinsi DIY. Di Kabupaten Sleman SMPN 4 Pakem dan SMPN 1 Godean memiliki prestasi dan indeks integritas UN yang tinggi meskipun sekolah ini terletak cukup jauh dari Kota Yogyakarta. Selain itu. SMPN 1 Kalasan dan SMPN 4 Depok yang memiliki in-tegritas yang cukup tinggi dan pencapaian nilai UN termasuk lima besar terbaik dibandingkan sekolah-sekolah lainnya di Kabupaten Sleman.

Itulah sebabnya penelitian ini memilih tiga SMP Negeri di Kabupaten Sleman sebagai Sekolah Menengah Pertama Negeri berprestasi. Ketiga sekolah tersebut adalah SMPN 1 Godean, SMPN 1 Kalasan, dan SMPN 4 Depok. Pemilihan ketiga sekolah ini didasarkan pada pencapaian hasil UN dan indeks integritas yang dimiliki masingmasing sekolah.

Berdasarkan uraian di atas dan penelitian-penelitian terkait, maka tujuan penelitian ini yakni (1) untuk menilai efektivitas implementasi standar proses pendidikan dalam pembelajaran; (2) untuk menganalisis faktor pendukung dan penghambat proses pembelajaran.

\section{Metode Penelitian}

Studi ini menggunakan jenis penelitian evaluasi dengan pendekatan kuantitatif. Model evaluasi yang digunakan adalah discrepancy evaluation model yang dikembangkan oleh Provus (1969, p. 167) untuk mengetahui tingkat efektivitas implementasi standar proses di SMPN 1 Godean, SMPN 1 Kalasan, dan SMPN 4 Depok.

Populasi penelitian ini adalah guruguru dari SMPN 1 Godean, SMPN $1 \mathrm{Ka}$ lasan, dan SMPN 4 Depok. Jumlah Populasi sampel disajikan pada Tabel 1.

Tabel 1. Populasi Penelitian

\begin{tabular}{clcc}
\hline No & Nama Sekolah & $\begin{array}{r}\text { Kepala } \\
\text { Sekolah }\end{array}$ & Guru \\
\hline 1 & SMP Negeri 1 Godean & 1 & 28 \\
2 & SMP Negeri 1 Kalasan & 1 & 45 \\
3 & SMP Negeri 4 Depok & 1 & 24 \\
& $\quad$ Jumlah & 3 & 97 \\
\hline
\end{tabular}

Berdasarkan jumlah populasi di atas, ditentukan ukuran sampel dengan menggunakan rumus dari Issac dan Michael (Sugiyono, 2014, p. 126). Dari rumus tersebut diperoleh sampel sebanyak 78 responden.

Langkah-langkah evaluasi discrepancy terhadap implementasi standar proses pendidikan dapat dilihat dalam desain berikut.

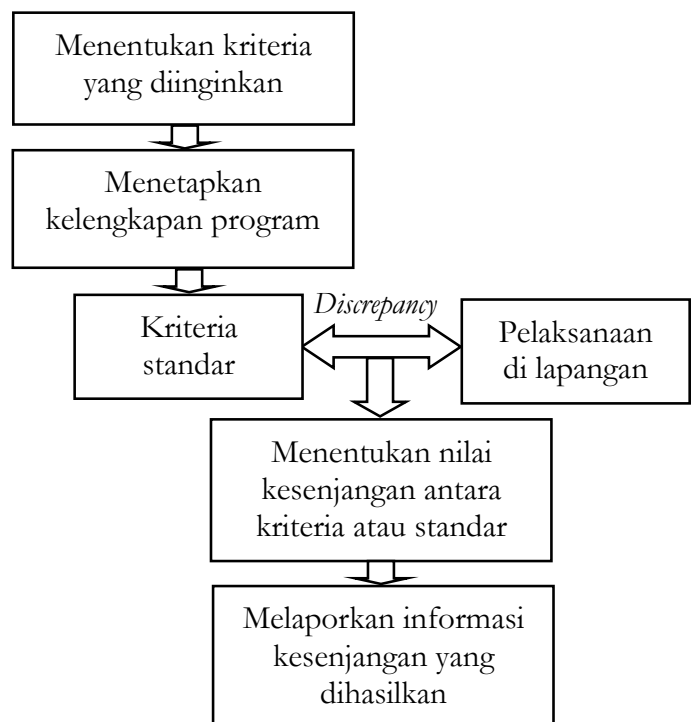

Gambar 1. Skema Tahap/Langkah Evaluasi Implementasi Standar Proses Pendidikan dengan Model Evaluasi Discrepancy Provus

Tahap pertama, peneliti mengidentifikasi kriteria dari standar proses dan teori pendukung evaluasi. Kedua, peneliti mengidentifikasi kelengkapan program keefektifan standar proses pendidikan SMPN 1 Godean, SMPN 1 Kalasan, dan SMPN 4 Depok. Ketiga, pelaksanaan standar proses pendidikan di SMPN 1 Godean, SMPN 1 Kalasan, dan SMPN 4 Depok dengan kriteria atau Standar Nasional Pendidikan. Keempat, mengidentifikasi kesenjangan (discrepancy) berupa persentase kesenjangan hasil capaian program. Kelima, peneliti memaparkan nilai kesenjangan (discrepancy) yang dihasilkan berdasarkan Standar Nasional Pendidikan di SMPN 1 Godean, SMPN 1 Kalasan, dan SMPN 4 Depok. Hasil evaluasi pelaksanaan Standar Nasional Pendidikan tersebut kemudian digunakan untuk mengungkap keefektifan standar proses pendidikan yang diterapkan dan kesen-

Evaluasi Pelaksanaan Standar Proses Pendidikan ... - 
jangan antara reliatas di lapangan dengan kriteria keberhasilan.

Pengumpulan data pada penelitian ini dilakukan dengan menggunakan angket, wawancara dan dokumentasi. Validitas instrumen penelitian melalui validitas internal. Pengujian validitas dengan validitas konstrak (construct validity). Setelah aspek-aspek pada instrumen dikonstruksi, instrumen tersebut dikonsultasikan kepada ahli (experts judgement). Selanjutnya instrumen diujicobakan. Uji coba instrumen dilakukan di SMPN 1 Sleman dengan jumal responden 30 guru. Responden tersebut tidak lagi terlibat dalam pengambilan data sebenarnya. Hasil pengujian validitas dan reliabilitas menunjukkan bahwa sebanyak 98 dari 123 item dinyatakan valid dan reliabel, sementara sisanya 25 item dinyatakan gugur.

Data yang terkumpul kemudian dianalisis dengan menggunakan teknik persentase. Adapun kriteria evaluasi keefektifan pelaksanaan standar proses yang digunakan dalam penelitian ini mengacu pada Permendiknas Nomor 41 tahun 2007 (Menteri Pendidikan Nasional Republik Indonesia, 2007a). Standar kriteria yang dimaksud meliputi: (1) Perencanaan proses pembelajaran: (a) Silabus; (b) Rencana Pelaksanaan Pembelajaran (RPP); (2) Pelaksanaan Pembelajaran; (3) Penilaian, dan (4) Pengawasan pembelajaran.

Derajat capaian standar proses diukur menggunakan pengklasifikasian kategori kriteria berdasarkan persentase capaian indikator skala empat.

\section{Hasil Penelitian dan Pembahasan}

Aspek Perencanaan Pembelajaran

Menyangkut aspek perencanaan pembelajaran, khususnya dalam penyusunan silabus dinilai dengan menggunakan 13 indikator. Total skor ketiga belas indikator dari aspek perencanaan pembelajaran dalam bentuk silabus di SMPN 1 Godean, SMPN 1 Kalasan, dan SMPN 4 Depok mencapai $94,58 \%$ dengan skor capaian 959 dari jumlah skor ideal 1.014. Selanjutnya aspek perencanaan dalam hal penyusunan rencana pelaksanaan pembelajaran (RPP) yang dinilai dengan menggunakan enam belas indikator memperoleh skor total mencapai $97,28 \%$ dengan skor 1.214 dari skor ideal 1.248.

Pada kegiatan persiapan pelaksanaan pembelajaran diketahui bahwa total indikator dari aspek persiapan pelaksanaan pembelajaran di SMPN SMPN 1 Godean, SMPN 1 Kalasan dan SMPN 4 Depok mencapai $97,18 \%$ dengan skor 758 dari skor ideal 780 . Lebih lanjut, kegiatan pendahuluan yang dinilai dari sepuluh indikator memperoleh total skor mencapai $96,15 \%$ dengan skor 750 dari skor ideal 780 .

\section{Aspek Pelaksanaan Pembelajaran}

Aspek pelaksanaan pembelajaran memiliki empat belas indikator. Total skor pelaksanaan pembelajaran di SMPN SMPN 1 Godean, SMPN 1 Kalasan dan SMPN 4 Depok dari keempat belas indikator tersebut mencapai 96,98\% dengan skor 1.059 dari skor ideal 1.092. Sedangkan pada kegiatan penutup dan tindak lanjut pelaksanaan pembelajaran diperoleh total skor mencapai $96,15 \%$ dengan skor 300 dari skor ideal 304 yang dinilai berdasarkan empat indikator.

Aspek Penilaian Pembelajaran

Aspek penilaian pembelajaran memiliki sembilan indikator. Total skor kesembilan indikator dari aspek pelaksanaan penilaian pembelajaran di SMPN 1 Godean, SMPN 1 Kalasan, dan SMPN 4 Depok mencapai 98,43\% dengan skor 691 dari skor ideal 702. Sedangkan total skor pemanfaatan hasil penilaian yang dinilai dari empat indikator mencapai $95,83 \%$ dengan skor 299 dari skor ideal 312.

Aspek Pengawasan Pembelajaran

Aspek pengawasan di SMPN 1 Godean, SMPN 1 Kalasan, dan SMPN 4 Depok memperoleh skor capaian 12 dari skor ideal 15. Indikator pelaksanaan pengawasan memperoleh skor capaian 21 dari skor ideal 21. Indikator pengecekan pengawasan memperoleh skor capaian 18 dari skor ideal 21. Indikator tindak lanjut dan pelaporan 
memperoleh skor capaian 24 dari skor ideal 24. Skor total keempat indikator dari aspek pengawasan pembelajaran di SMPN 1 Godean, SMPN 1 Kalasan, dan SMPN 4 Depok mencapai $96,15 \%$ dengan skor 75 dari jumlah skor ideal 78.

Faktor Pendukung dan Penghambat Pembelajaran

Faktor pendukung dan penghambat pembelajaran yang dapat digali melalui penelitian ini adalah: (1) guru merasa terbantu dalam pembuatan silabus dengan adanya pelatihan yang diselenggarakan pihak sekolah dengan skor capaian 72 dari skor ideal 78. (2) guru merasa terbantu dalam pembuatan RPP dengan adanya pelatihan yang diselenggarakan pihak sekolah (74 dari skor ideal 78). (3) guru merasa terbantu dalam kegiatan pembelajaran oleh fasilitas pembelajaran yang memadai dengan skor capaian 74 dari skor ideal 78. (4) guru merasa terbantu dalam kegiatan pembelajaran dengan lingkungan kelas yang kondusif (skor 77 dari skor ideal 78). (5) guru merasa terbantu dalam kegiatan pembelajaran oleh peserta didik yang kooperatif dengan skor capaian 77 dari skor ideal 78. (6) guru merasa mencapai tujuan pembelajaran karena peserta didik mampu memahami materi dengan baik (skor perolehan 73 dari skor ideal 78). (7) guru merasa terbantu dengan arahan kepala sekolah dalam menganalisis butir soal (skor capaian 66 dari skor ideal 78). (8) Indikator guru dapat mengetahui hasil belajar dengan jelas karena pelaksanaan evaluasi sesuai jadwal dengan skor 69 dari skor ideal 78 .

Dengan demikian terdapat delapan aspek pendukung pembelajaran di SMPN 1 Godean, SMPN 1 Kalasan, dan SMPN 4 Depok dengan skor perolehan mencapai 93,27\% dengan skor 582 dari jumlah skor ideal 624, yaitu pelatihan penyusunan silabus, pelatihan penyusunan RPP, fasilitas yang memadai, lingkungan kelas yang kondusif, peserta didik yang kooperatif, ketercapaian tujauan pembelajara, arahan kepala sekolah dalam menganalisis butir soal serta jadwal pelaksanaan evaluasi yang tepat waktu.

Selain delapan faktor pendukung pelaksanaan standar proses pendidikan, terdapat beberapa faktor penghambat, yaitu: (1) guru merasa kesulitan dalam merancang pembelajaran aktif bagi peserta didik. (2) guru merasa kesulitan dalam menentukan metode yang tepat sesuai dengan karakteristik peserta didik. (3) guru merasa kurang mampu menginovasikan media pembelajaran. (4) guru merasa kurang mampu mengaplikasikan metode yang sesuai dengan kondisi peserta didik. (5) guru merasa kesulitan untuk memotivasi kemauan belajar peserta didik. (6) guru merasa kekurangan informasi baru (misalnya materi tambahan) yang sesuai dengan usia dan tingkatan kemampuan belajar peserta didik. (7) guru merasa kesulitan mengidentifikasi kemampuan peserta didik.

Evaluasi Pelaksanaan Pembelajaran

Hasil evaluasi pelaksanaan pembelajaran di SMPN 1 Godean, SMPN $1 \mathrm{Ka}$ lasan, dan SMPN 4 Depok dapat dilihat dari Tabel 2.

Tabel 2. Aspek Evaluasi Proses Pembelajaran

\begin{tabular}{|c|c|c|c|}
\hline No & Indikator & Skor & $\begin{array}{l}\text { Skor } \\
\text { Ideal }\end{array}$ \\
\hline 1 & Silabus & 94,58 & 100 \\
\hline 2 & RPP & 97,28 & 100 \\
\hline 3 & Persiapan Pembelajaran & 97,18 & 100 \\
\hline 4 & Kegiatan Pendahuluan & 96,15 & 100 \\
\hline 5 & Kegiatan Pelaksanaan & 96,98 & 100 \\
\hline 6 & Kegiatan Penutup & 96,15 & 100 \\
\hline 7 & $\begin{array}{l}\text { Pelaksanaan Penilaian } \\
\text { Pembelajaran }\end{array}$ & 98,43 & 100 \\
\hline 8 & $\begin{array}{l}\text { Pemanfaatan Hasil } \\
\text { PenilaianPembelajaran }\end{array}$ & 96,15 & 100 \\
\hline 9 & $\begin{array}{l}\text { Tindak Lanjut Hasil } \\
\text { Penilaian Pembelajaran }\end{array}$ & 95,72 & 100 \\
\hline 10 & Pendukung pembelajaran & 93,27 & 100 \\
\hline 11 & Penghambat pembelajaran & 32,23 & 100 \\
\hline 12 & Pengawasan Pembelajaran & 96,15 & 100 \\
\hline & Jumlah Skor & $1.090,27$ & 1.200 \\
\hline & Rata-rata & 90,86 & 100 \\
\hline & Standar Deviasi & \multicolumn{2}{|c|}{18,51} \\
\hline
\end{tabular}

Evaluasi Pelaksanaan Standar Proses Pendidikan ... - 
Selanjutnya dapat ditunjukkan capaian implementasi proses pembelajaran dari ketiga SMPN di Kabupaten Sleman berdasarkan komponen evaluasi pembelajaran standar proses pada Tabel 3 .

Tabel 3. Capaian Implementasi Standar Proses Pendidikan

\begin{tabular}{|c|c|c|c|}
\hline No & Aspek & $\begin{array}{l}\text { Skor } \\
\text { Capaian } \\
(\%)\end{array}$ & $\begin{array}{l}\text { Kesen- } \\
\text { jangan }\end{array}$ \\
\hline \multirow[t]{4}{*}{1} & Perencanaan Pembelajaran & & \\
\hline & a. Silabus & 94,58 & 5,42 \\
\hline & b. RPP & 97,28 & 2,72 \\
\hline & Rata-rata & 95,93 & 4,07 \\
\hline \multirow[t]{6}{*}{2} & Pelaksanaan Pembelajaran & & \\
\hline & a. Persiapan Pembelajaran & 97,18 & 2,82 \\
\hline & b. Kegiatan Pendahuluan & 96,15 & 3,85 \\
\hline & c. Kegiatan Pelaksanaan & 96,98 & 3,02 \\
\hline & d. Kegiatan Penuutup & 96,15 & 3,85 \\
\hline & Rata-rata & 96,62 & 3,38 \\
\hline \multirow[t]{4}{*}{3} & $\begin{array}{l}\text { Penilaian Pembelajaran } \\
\text { a. Pelaksanaan Penilaian } \\
\text { Pembelajaran }\end{array}$ & 98,43 & 1,57 \\
\hline & $\begin{array}{l}\text { b. Pemanfaatan Hasil } \\
\text { Penilaian Pembelajaran }\end{array}$ & 96,15 & 3,85 \\
\hline & $\begin{array}{l}\text { c. Tindak Lanjut Hasil } \\
\text { Penilaian Pembelajaran }\end{array}$ & 95,72 & 4,28 \\
\hline & Rata-rata & 96,77 & 3,23 \\
\hline \multirow[t]{3}{*}{4} & Pengawasan Pembelajaran & & \\
\hline & $\begin{array}{l}\text { a. Kegiatan Pengawasan } \\
\text { Pembelajaran }\end{array}$ & 96,15 & 3,85 \\
\hline & Rata-rata & 96,15 & 3,85 \\
\hline \multirow[t]{3}{*}{5} & Dukungan Pembelajaran & & \\
\hline & $\begin{array}{l}\text { Pendukung } \\
\text { pembelajaran yang } \\
\text { membantu guru dalam } \\
\text { pelaksanaan } \\
\text { pembelajaran }\end{array}$ & 3,23 & 67,77 \\
\hline & Rata-rata & 3,23 & 67,77 \\
\hline \multirow[t]{5}{*}{6} & Hambatan Pembelajaran & & \\
\hline & $\begin{array}{l}\text { a. Penghambat } \\
\text { pembelajaran yang } \\
\text { membantu guru dalam } \\
\text { pelaksanaan } \\
\text { pembelajaran }\end{array}$ & 30,45 & 69,55 \\
\hline & Rata-rata & 30,45 & 69,55 \\
\hline & Rata-rata total & 90,86 & 9,14 \\
\hline & Standar Deviasi & \multicolumn{2}{|c|}{18,51} \\
\hline
\end{tabular}

Capaian implementasi standar proses pendidikan pada SMPN 1 Godean, SMPN 1 Kalasan dan SMPN 4 Depok dari kelima aspek memperlihatkan rata-rata total skor capaian 90,86 dengan kesenjangan (discrepancy) mencapai 9,14.

Setelah mendapatkan data hasil berupa data kuantitatif yang menunjukkan skor rata-rata adalah 90,86\% dengan standar deviasi $18,51 \%$, data tersebut dibandingan dengan tabel kriteria yang disusun berdasarkan rerata dan standar deviasi ideal seperti yang ditunjukkan pada Tabel 4.

Tabel 4. Kriteria Evaluasi

\begin{tabular}{ccc}
\hline Nilai & Interval Skor & Kriteria \\
\hline A & $\mathrm{X}<-1 \mathrm{SB}$ & Kurang efektif \\
& $\mathrm{X}<52.14$ & \\
$\mathrm{~B}$ & $\mathrm{X}<\mathrm{X}-1 \mathrm{SB}$ & Cukup efektif \\
& $6411<\mathrm{X} \geq 5214$ & \\
C & $\mathrm{X}+1 \mathrm{SB}>\mathrm{X} \geq \mathrm{X}$ & Efektif \\
& $76,08>\mathrm{X} \geq 64.11$ & \\
D & $\mathrm{X}+1 \mathrm{SB}$ & Sangat efektif \\
& $\mathrm{X} \geq 76,08$ & \\
\hline
\end{tabular}

Keterangan:

$\mathrm{X}=$ Rerata skor ideal

$=1 / 2(100+28,21)=64.11$

$\mathrm{SB}=$ Simpangan baku skor ideal

$=1 / 6(100-28.21)=11.97$

Berdasarkan deskripsi data pada Tabel 4, maka proses pembelajaran, mulai dari perencanaan, pelaksanaan, penilaian, pengawasan, kegiatan tindak lanjut serta faktor pendukung dan penghambat pembelajaran merupakan aspek terpenting dalam penyelenggaraan pendidikan di sekolah. Oleh karena itu mutu pendidikan di sekolah dapat diukur dari, pertama, efektivitas perencanaan pembelajaran yang berkaitan dengan silabus maupun RPP merupakan salah satu tahapan penting dalam sistem pembelajaran. Sebagaimana yang dikemukakan oleh Newman (Majid, 2008, pp. 15-16) bahwa perencanaan pembelajaran adalah proses memilih, menetapkan dan mengembangkan pendekatan, metode dan teknik pembelajaran, menawarkan bahan ajar, dan menyediakan pengalaman belajar yang bermakna ser- 
ta mengukur tingkat keberhasilan proses pembelajaran dalam mencapai hasil pembelajaran. Hasil penelitian secara umum menunjukkan bahwa pencapaian pelaksanaan pe-rencanaan pembelajaran yang dilakukan oleh guru rata-rata tercapai dengan kriteria "Sangat Efektif". Hal tersebut berarti pelaksanaan perencanaan pembelajaran sudah sesuai dengan standar proses pembelajaran dimana hampir seluruh guru telah menyusun rencana pembelajaran dengan maksimal, meskipun terdapat beberapa guru yang tidak menganalisis ulang Standar Kompetensi (SK) dan Kompetensi Dasar (KD) yang ada pada Standar Isi (SI) pada penyusunan silabus atau mengkaji ulang RPP yang dibuat.

Kedua, efektivitas pelaksanaan kegiatan pembelajaran SMPN 1 Godean, SMPN 1 Kalasan dan SMPN 4 Depok secara umum telah tercapai dengan kriteria "Sangat Efektif'. Pelaksanaan kegiatan pembelajaran yang dilaksanakan oleh guru telah sesuai dengan standar proses pembelajaran. Hasil penelitian menunjukkan bahwa pelaksanaan kegiatan pembelajaran yang dilakukan guru di setiap sekolah jika diurutkan skor ketercapaian pelaksanaan perencanaan pembelajaran dari yang tertinggi menurut sekolah, yaitu SMPN 4 Depok, SMPN 1 Godean, dan SMPN 1 Kalasan. Lebih lanjut, Majid (2008, p. 19) mengungkapkan bahwa proses belajar mengajar merupakan interaksi yang dilakukan antara guru dan peserta didik dalam suatu pengajaran untuk mewujudkan tujuan yang telah ditetapkan. Oleh karena itu dalam proses belajar mengajar diharapkan guru tidak mendominasi kegiatan pembelajaran yang dapat membuat peserta didik menjadi pasif. Guru berkewajiban untuk mempersiapkan metode atau strategi serta media yang sesuai dengan materi yang diajarkan dan karakteristik peserta didik sehingga dapat menarik minat peserta didik dalam mengikuti kegiatan pembelajaran.

Ketiga, efektivitas penilaian proses pembelajaran SMPN 1 Godean, SMPN 1 Kalasan dan SMPN 4 Depok yang terdiri dari tiga aspek, yaitu, pelaksanaan penilaian, pemanfaatan hasil penilaian pembelajaran dan tindak lanjut hasil penilaian pembelajaran tercapai dengan kriteria "Sangat Efektif”. Hal tersebut menunjukkan bahwa pelaksanaan penilaian pembelajaran yang dilaksanakan oleh guru telah sesuai dengan standar proses pembelajaran. Hasil penelitian menunjukkan bahwa aspek penilaian proses pembelajaran di setiap SMP dapat diurutkan skor capaian aspek penilaian proses pembelajaran mulai dari SMPN 1 Godean, SMPN 1 Kalasan dan SMPN 4 Depok. Lebih lanjut, Permendiknas Nomor 20 Tahun 2007 (Menteri Pendidikan Nasional Republik Indonesia, 2007b) menyatakan bahwa pelaksanaan penilaian hasil belajar peserta didik pada pendidikan dasar dan menengah dilakukan berdasarkan pada prinsip-prinsip yang meliputi: (1) sahih; (2) objektif; (3) adil; (4) terpadu; (5) terbuka; (6) menyeluruh dan berkesinambungan; (7) sistematis; (8) beracuan kriteria; (9) akuntabel.

Keempat, efektivitas pengawasan atau supervisi proses pembelajaran di SMPN 1 Godean, SMPN 1 Kalasan dan SMPN 4 Depok. Prasojo \& Sudiyono (2011, p. 1) mengungkapkan bahwa "supervisi merupakan kegiatan bantuan pembinaan ke arah perbaikan pembelajaran". Dari pernyataan tersebut dapat terlihat bahwa tujuan dari supervisi yaitu perbaikan pembelajaran. $\mathrm{Hal}$ tersebut dapat dilakukan apabila kepala sekolah melaksanakan kegiatan pengawasan secara rutin untuk mengetahui kelemahankelemahan proses pembelajaran yang dilakukan oleh guru.

Berdasarkan hasil penelitian pada aspek pengawasan, kepala sekolah mengisi seluruh pernyataan dari peneliti dengan jawaban "Ya", hal tersebut menunjukkan bahwa Kepala Sekolah SMPN 1 Godean telah melaksanakan pengawasan sesuai prosedur dengan baik. Namun dalam hal melakukan perencanaan dan pemetaan dalam pengawasan pembelajaran yang meliputi pemantauan, supervisi, dan evaluasi proses pembelajaran belum dilakukan. Hal tersebut menunjukkan bahwa selama ini kepala sekolah belum turut serta dalam merencanakan metode pengawasan pembelajaran dan tidak melakukan pemetaan pengawasan 
pembelajaran. Pelaksanaan pengawasan pembelajaran dibagi ke dalam 4 (empat) aspek, yaitu aspek perencanaan pengawasan, pelaksanaan pengawasan, pengecekan dan tindaklanjut atau pelaporan. Dari keempat aspek tersebut aspek yang memiliki capaian terendah, yaitu aspek perencanaan pengawasan. Secara keseluruhan, pelaksanaan pengawasan di SMPN 1 Godean, SMPN 1 Kalasan dan SMPN 4 Depok memperoleh capaian dengan kriteria "Sangat Efektif', artinya pelaksanaan pengawasan sudah sesuai dengan standar proses pembelajaran.

Selanjutnya, hasil penelitian menunjukkan bahwa terdapat delapan aspek pendukung pembelajaran di SMPN 1 Godean, SMPN 1 Kalasan, dan SMPN 4 Depok dengan skor perolehan mencapai 93,27\% dengan skor 582 dari jumlah skor ideal 624, yaitu pelatihan penyusunan silabus, pelatihan penyusunan RPP, fasilitas yang memadai, lingkungan kelas yang kondusif, peserta didik yang kooperatif, ketercapaian tujauan pembelajara, arahan kepala sekolah dalam menganalisis butir soal serta jadwal pelaksanaan evaluasi yang tepat waktu.

Hambatan pembelajaran yang dialami oleh guru diuraikan menjadi tujuh indikator, yaitu: (1) guru merasa kesulitan dalam merancang pembelajaran aktif bagi peserta didik; (2) guru merasa kesulitan dalam menentukan metode yang tepat sesuai dengan karakteristik peserta didik; (3) guru merasa kurang mampu menginovasikan media pembelajaran; (4) guru merasa kurang mampu mengaplikasikan metode yang sesuai dengan kondisi peserta didik; (5) guru merasa kesulitan untuk memotivasi kemauan belajar peserta didik. (6) guru merasa kekurangan informasi baru (misalnya materi tambahan) yang sesuai dengan usia dan tingkatan kemampuan belajar peserta didik. (7) guru merasa kesulitan mengidentifikasi kemampuan peserta didik.

\section{Simpulan}

Berdasarkan hasil analisis yang dilakukan dapat disimpulkan bahwa efektivitas implementasi standar proses pendidikan pada aspek perencanaan pembelajaran, pe- laksanaan, penilaian, dan pengawasan di SMPN 1 Godean, SMPN 1 Kalasan dan SMPN 4 Depok telah tercapai dengan kriteria 'Sangat Efektif'. Selanjutnya, diketahui bahwa terdapat delapan faktor yang mendukung terlaksanaanya standar proses pendidikan di sekolah, yaitu pelatihan penyusunan silabus, pelatihan penyusunan RPP, fasilitas yang memadai, lingkungan kelas yang kondusif, peserta didik yang kooperatif, ketercapaian tujauan pembelajara, arahan kepala sekolah dalam menganalisis butir soal serta jadwal pelaksanaan evaluasi yang tepat waktu. Selain itu terdapat tujuh aspek yang menghambat pelaksanaan standar proses atau kesulitan yang dihadapi guru dalam pelaksanaan standar proses, yakni kesulitan dalam merancang pembelajaran aktif bagi peserta didik, menentukan metode yang tepat sesuai dengan karakteristik peserta didik, menginovasikan media pembelajaran, mengaplikasikan metode yang sesuai dengan kondisi peserta didik, memotivasi kemauan belajar peserta didik, memperoleh informasi baru yang sesuai dengan usia dan tingkatan kemampuan belajar peserta didik serta kesulitan dalam mengidentifikasi kemampuan peserta didik.

Berdasarkan hasil tersebut, maka disarankan bagi kepala sekolah untuk menyelenggarakan pengawasan dan evaluasi pembelajaran secara rutin, dengan terlebih dahulu melakukan perencanaan dan pemetaan, sehingga dapat meningkatkan peran guru melaksanakan standar proses pembelajaran. Kepala sekolah juga perlu menyelenggarakan pelatihan dan diskusi rutin untuk perbaikan pembelajaran agar guru dapat menyelesaikan permasalahan-permasalahan yang dihadapi dalam proses pembelajaran. Selain itu, guru diharapkan dapat mengevaluasi perencanaan pembelajaran yang disesuaikan dengan kondisi peserta didik dan karakterisktik materi pelajaran secara rutin.

\section{Daftar Pustaka}

Lestarini, A. H. (2014). Rangking mutu pendidikan RI di dunia paling jeblok. Okerone News. Retrieved from https://news.okezone.com/read/2014 
/05/13/373/984246/rangking-mutupendidikan-ri-di-dunia-paling-jeblok

Majid, A. (2008). Perencanaan pembelajaran mengembangkan standar kompetensi guru. Bandung: PT. Remaja Rosdakarya.

Menteri Pendidikan Nasional Republik Indonesia. Peraturan Menteri Pendidikan Nasional Republik Indonesia Nomor 41 Tahun 2007 tentang Standar Proses untuk Satuan Pendidikan Dasar dan menengah (2007).

Menteri Pendidikan Nasional Republik Indonesia. Permendiknas nomor 20 tahun 2007 tentang standar penilaian pendidikan (2007).

Prasojo, L. D., \& Sudiyono. (2011). Supervisi pendidikan. Yogyakarta: Gava Media.

Provus, M. (1969). The discrepancy evaluation modelan approach to local program improvement and development. Pensylvania: PittsburgPublic School.

Sugiyono. (2014). Metode penelitian pendidikan pendekatan kuantitatif, kualitatif, dan R \& $D$. Bandung: Alfabeta.

Usman, H. (2014). Manajeman: teori, praktik, dan riset pendidikan (4th ed.). Jakarta: PT Bumi Aksara. 